DOI: https://doi.org/10.18371/fp.2(34).2019.183583

УДК 336

\title{
ФІНАНСОВИЙ МЕХАНІЗМ ФУНКЦІОНУВАННЯ АГРАРНИХ ПІДПРИЄМСТВ: ЗАРУБІЖНИЙ ДОСВІД
}

\section{СИНЕНКО Олександр Олександрович}

аспірант кафедри економіки та фінансів

ДВНЗ «Херсонський держсавний аграрний університет»

Анотація. У статті досліджено досвід провідних країн світу у формуванні фінансового механізму ефективноі діяльності аграрних підприємств. Виявлено, щзо на ефективність фінансового механізму аграрних господарств має значний вплив державне втручання в частині підтримки сільського господарства через дотачії, регулювання иін, застосування квот, кредитної й податкової політики тощзо. Визначено інструменти впливу зарубіжних краӥн на фінансовий механізм, які було б доиільно адаптувати й застосовувати в Украӥні.

Ключові слова: фінансовий механізм, держава, державний вплив, державне регулювання, ціна, ціноутворення.

Постановка проблеми. Для забезпечення успішної діяльності в ринкових умовах кожен господарюючий суб'єкт аграрної сфери повинен приділяти увагу різним аспектам своєї діяльності. Одним з головних аспектів є формування ефективного фінансового механізму. Кардинальні зміни в економічній та фінансовій сферах, що відбулися за останній час в Україні, змушують замислитись про існуючі теоретичний i методичний підходи щодо вибору інструментів формування фінансового механізму. Крім того, потребують ретельного дослідження та аналізу існуючі
Аннотация. $B$ cmamье исследованы опыт ведущих стран мира в формировании финансового механизма эффективной деятельности аграрных предприятий. Выявлено, что на эффективность финансового механизма аграрных хозяйств может влиять государственное вмешательство путём поддержки сельского хозяйства через дотации, цеены, квоты, кредитную и налоговую политику и тому подобное. Определень инструменть влияния зарубежных стран на финансовый механизм, которые было бы иелесообразно адаптировать и применять в Украине.

Ключевые слова: финансовый механизм, государство, государственное влияние, государственное регулирование, цена, ценообразование.

інструменти формування, які застосовуються в зарубіжних країнах.

Аналіз останніх досліджень та публікацій. Дослідження різноманітності підходів до формування фінансового механізму за рахунок державної підтримки аграрного підприємництва, що використовуються у міжнародній практиці здійснено у працях Марти-Кости А. та Сільви Е., Майстро С.В., Моріссона Дж.Р., Назаркевича О.Б., Собкевича О.В., Русана В.М., Юрченка А.Д., Ковальова О.В., Жураковської Л.А. та інших.

Неоднозначність результатів досліджень вчених щодо дієвості ви- 
користовуваних

підтримки діяльності

інструментів шідер об єктивну потребу подальших досліджень.

Метою даної статті $€$ дослідження досвіду формування фінансового механізму сільськогосподарських підприємств провідних країв світу та можливість його адаптації до реалій України.

Виклад основного матеріалу. На фінансовий механізм впливають світові фінансові процеси та глобалізація, тому є доцільним адаптувати провідний досвід зарубіжних країн. Міжнародний досвід свідчить, що реформування фінансового механізму аграрних підприємств проходить в основному за рахунок посилення прямих i непрямих важелів державного впливу. Державний вплив здійснюється шляхом регулювання цін на продукцію сільськогосподарських виробників i фермерських доходів, бюджетного фінансування діяльності аграріїв, забезпечення доступного кредитування, прозорого і зрозумілого оподаткування, регулювання експорту та імпорту аграрної продукції, стабілізації ринку сільськогосподарської продукції, регулювання земельних відносин, допомога господарствам, що знаходяться в несприятливих кліматичних умовах, підтримка науково-технічного прогресу, соціальна під-тримка фермерів тощо. Успіх сільського господарства провідних країн Західної Свропи, США, Канади, Китаю, Японії зобов'язаний обмеженню дій ринкових механізмів саморегулювання 3 використанням зовнішніх важелів впливу. Це державна підтримка сільського господарства через дотації, ціни, квоти, кредитну й податкову політику тощо $[1,2]$.

Крім того, не залежно від рівня розвитку економіки країни, саме державне регулювання визначає стан та рівень розвитку фінансування аграрного сектору, оскільки саме через свої особливості виробництва він вимагає значної участі держави у своїй діяльності. На сьогодні у світі функціонує два найбільш ефективних підходи до державного регулювання: північноамериканський та європейський $[3,4]$. Головними відмінностями цих підходів $є$ те, що другий підхід має більшу соціальну орієнтованість, а перший орієнтований на підвищення конкурентоспроможності й захист фермерів (рис. 1).

У розвинутих країнах Заходу забезпечення ефективного функціонування фінансового механізму аграрних підприємств, а також їх підтримка у вигляді дотацій, субсидій i різних компенсаційних виплат, $є$ однією 3 пріоритетних задач економічної політики держави.

Сільське господарство США $\epsilon$ пріоритетним та важливим напрямом розвитку економіки країни. Воно має постійне державне забезпечення й регулювання в усіх сферах його роботи. Аграрне законодавство США $є$ гнучким, що дозволяє охопити всі сторони сільського господарства. Перші базові державні фінансові механізми регулювання були закладені ще у законодавстві 1933 та 1938 років. Першоджерелом державного регулювання в США вважається законодавство «Нового курсу» Франкліна Д. Рузвельта, в якому визначалися основи 
цільової підтримки аграрного сектору економіки країни. Кожні п'ять років програми підтримки розвитку сільського господарства переглядаються в рамках законодавчого пакета «Про сільське господарство». У 1937 році було прийнято Акт сільськогосподарських маркетингових угод, а також вводиться підтримка цін на продукцію фермерських господарств. Пізніше були підписані сільськогосподарські акти направлені на стимулювання попиту на продукцію аграрних

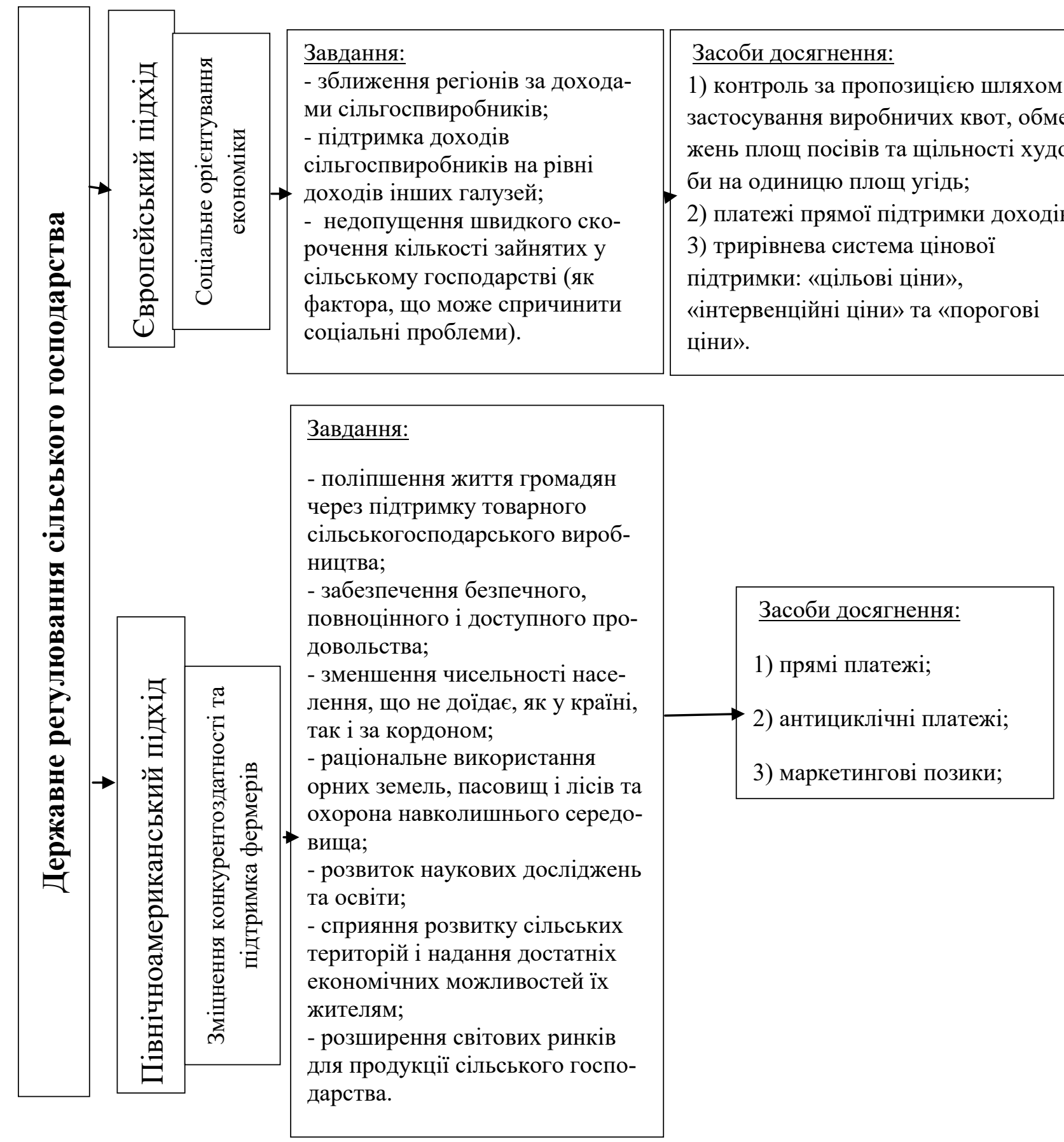

Рис. 1. Світові підходи до державного регулювання сільського господарства * *3груповано автором за даними [5,6] 
За цими актами були введені програми продовольчих талонів та безкоштовних сніданків у школах. У 1970 роках в сільськогосподарських актах приділялася увага заходам, які були спрямовані на освоєність ринків інших країн, доступність продукції на внутрішніх ринка США, стимулювався експорт виготовленої продукції сільського господарства [6,7].

У США в 80-ті роки підписані сільськогосподарські акти передбачали активну підтримку фермерського господарства. В цих актах було зазначено, що фермери мали право отримувати підтримку своєї діяльність у формі різноманітних заставних позик, компенсаційних платежів тощо. Також у цих актах передбачався контроль за посівними площами, фермери отримували виплати у випадку настання стихійного лиха, формувалися так званні фермерські резерви, виплачувалися експортні субсидії та вівся активних ціновий контроль та підтримка у разі настання ембарго на експорт продукції американських аграрних товаровиробників.

Починаючи 3 90-х років підписувались сільськогосподарські акти, які були направлені на орієнтування фермерів на ринкові сигнали, але при цьому вагомою залишалася державна підтримка. За даними збірників

i3 сільськогосподарської статистики США прямі державні виплати в чистому фермерському доході становили в 1999 році $45,1 \%$, а у 2000 -му - 46,8 $\%$ [3]. У 2000-них роках в США державні програми для фермерських господарств відповідно до положень Акту фермерської безпеки та розвитку інвестування в сільській місцевості. У 2013 році рівень державної підтримки фермерів знизився до 7,3 \%. Цьому сприяли зміни у державній аграрній політиці, вплив політики СОТ, конкуренція 3 боку інших держав, а також сприятлива для фермерів динаміка цін на ринку аграрної продукції [6].

У лютому 2014 року вступив у дію Фермерський акт, чинність якого закінчується в кінці 2018 року. Розділи даного Акту направлені на регулювання відносин між державою та виробниками i споживачами продукції сільського господарств та продовольства у сфері виробництва продукції аграріїв, страхування рослинництва, консервації земельних ресурсів, кредитування, розвитку сільських територій, наукових досліджень і дорадництва. На виконання всіх необхідних заходів, передбачених Фермерським актом, було заплановано витратити 489 млрд дол. США. 3 цієї суми на реалізацію продовольчих програм призначено 80\% коштів, на страхування сільськогосподарських ризиків - 8\%, на різноманітні товарні програми $5 \%$, на інші програми - решта $7 \%$.

Сьогодні у США одним із головних напрямів регулювання агропромислового комплексу є регулювання цін на сільськогосподарську продукцію [8]. Вже протягом кількох десятиліть в США офіційно існують два види «цін підтримки»:

1) Цільові (гарантовані) ціни - визначають нижній рівень фермерських доходів. Цей вид не функціонує на ринку, а застосовується в розрахунках 
працівників апарату регулювання цін і доходів для визначення компенсаційної цінової надбавки. Використання цільових цін дозволяє уряду визначати нижній рівень доходів в сільському господарстві і надалі встановлювати джерела фінансування фермерських доходів. Так, якщо ціни реалізації вищі цільових, фермери одержують дохід виключно за рахунок споживачів. У разі падіння ринкових цін нижче за рівень цільових набуває чинності механізм прямої підтримки фермерських доходів через надбавки до ринкових цін у формі прямих урядових платежів [8].

2) Заставні ціни. За заставною ціною фермер віддає Товарно-кредитній корпорації свою продукцію у тому випадку, якщо ціни встановлюються нижче цін на світовому ринку. Виникненню заставної ціни сприяв високий рівень цін на внутрішньому ринку США, що заважав експорту продукції. При цьому цільова ціна, яка визначала рівень дохідності фермерів, не мала можливості втримати ринкову ціни від падіння.

Не менш вадливою для розвитку сільського господарства США є система фінансування аграрного сектора. У США було створено спеціалізовані заклади кредитування фермерів. Сільською кредитною кооперацією опікується Міністерство сільського господарства. Фермери можуть отримати кредит з варіацією відсоткових ставок від 1,5 до 8\% річних. На 2017 рік за статистичними даними Служби економічних досліджень заборгованість американських фермерів перед кредитними організаціями становила лише $12 \%$ від загального обсягу наявних активів. Це свідчить про достатню акумуляцію власних коштів для забезпечення діяльності фермерів. Хоча необхідно відзначити, що цей показник $є$ середнім і деякі фермери мають набагато більше співвідношення боргу до активів. Основним постачальником кредитних ресурсів під заставу нерухомого майна $є$ Система фермерського кредиту (СФК). В структурі балансу сільськогосподарських підприємств США, питома вага кредитів перед СФК в загальному обсязі кредитів під заставу нерухомого майна становить $46 \%$. СФК є унікальною структурою, вона побудована на кооперативних засадах. Ïї створили в 1916 році на підставі Федерального Закону про фермерський кредит. Це дворівнева кооперативна система, де на першому рівні функціонують кредитні асоціації, а на другому - кооперативні банки. Членами кредитних асоціацій $\epsilon$ сільськогосподарські виробники, а членами кооперативних банків $є$ кредитні асоціації. Особливістю СФК є те, що переважно кредитні ресурси система залучає за рахунок випуску боргових цінних паперів на національних фінансових ринках. Ставки за кредит коливаються від 4 до 8\% залежно від термінів та призначення кредиту. Також беруть активну участь у кредитування фермерів в США і звичайні комерційні банки, але вони не можуть фермерам запропонувати фіксовану відсоткову ставку $[9,10]$.

Таким чином, можна зробити висновок, що фермери США залучені ефективною державною підтримкою. Державне регулювання спирається на жорсткий контроль цін на продукцію сільського господарства, доступність 
фінансування діяльності аграріїв. Потреби фермерів у кредитних ресурсах задоволені в повній мірі в необхідний час, у повному обсязі та за помірною вартістю.

Досвід розвитку сільського господарства в країна $\mathrm{CC}$ також говорить про важливу роль держави та державної підтримки в цьому процесі. Державне регулювання аграрної політики було закладено ще у статтях Римської угоди. Саме в цьому документі були визначені основи спільної аграрної політики (САП) країн СС. У Римській угоді були прописані положення щодо сільськогосподарської продукції, яка має включатися в єдиний ринок, завдань спільної агарної політики, заходів підтримки досліджень в аграрній сфері. Напрями спільної агарної політики постійно удосконалювались й оновлювалися під пильним контролем європейської спільноти, Ради Європи та Європейської комісії. Спільна аграрна політика 2014-2020 років орієнтована на цілеспрямовану суспільну підтримку аграрного сектора, підвищенні довгострокової продуктивності, стійкість та стабільність ефективного сільського господарства. На САП 2014-2020 років на реалізацію запланованих заходів виділяється 363 млрд євро. САП включає такі дві складові [11]:

- перша складова включає в себе фінансові заходи підтримки фермерів. Були удосконалені схеми єдиного платежу та єдиного територіального платежу.

- друга складова акцентована на заходи щодо розвитку сільського господарства.

У Свропі державне регулювання сільського господарства має економічне спрямування. Однією з найважливіших функцій державного регулювання $\epsilon$ регламентування кількості й якості виробленої продукції шляхом контролю за організаційно-економічною структурою виробництва, зокрема заохоченням кооперації та вертикальної інтеграції, що має вплив на галузеву спеціалізацію виробництва сільськогосподарських продуктів і порядок постачання ними населення.

В СС важливим аспектом ефективного фінансового механізму є державне регулювання цін на продукцію сільського господарства. На більшу частину продукції аграрних товаровиробників регулювання цін здійснюється наднаціональними органами. Рішення про ціни підтримки і комплекс пов'язаних з ними заходів приймає Рада Міністрів ЄС на рівні міністрів сільського господарства. В СС ціни підтримки мають такі форми [12]:

1) Інтервенційна ціна - це мінімальна ціна, яка $\epsilon$ гарантованою державою. За нею держава та закупівельні організації зобов'язані закуповувати продукцію сільського господарства у фермерів за умови, що фактично діючі ринкові ціни знижуються до ії рівня. Закуповуючи продукцію за інтервенційними цінами, держава регулює кон'юнктуру ринку, тим самим не даючи ринковим цінам опускатися нижче межі, за якою господарства не будуть в змозі вести розширене відтворення. За цими цінами держава може придбати продукції лише в межах встановлених квот на закупку тієї чи іншої продукції.

2) Цільова ціна - це ціни, які встановлені $з$ метою визначення бажаних 
ринкових цін. На деякі види продукції вводять низькі за характером і функціями орієнтовні, базисні, нормальні ціни. В свою чергу цільова ціна має два різновиди: контрольна ціна та орієнтовна ціна. Контрольна ціна встановлюється на бездефіцитну в країнах Спільного ринку аграрну продукцію (зерно, овочі, фрукти тощо), що експортується в інші країни, з урахуванням рівня цін, що діють у регіонах 3 переважаючими умовами ії виробництва. Орієнтовна ціна поширюється на дефіцитну в ЄС продукцію аграріїв (телятину, м'ясо великої рогатої худоби тощо). Також цільова ціна $є$ фундаментом для встановлення порогових та шлюзових цін. У країнах $\mathrm{CB}$ ці ціни служать захистом внутрішніх фермерських цін від низьких цін у світі. Порогові ціни встановлюються на імпортовану продукцію так, щоб їх рівень був дещо вищим за цільову ціну.

Таким чином, можна зробити висновок, що державне регулювання цін в країнах Свропейського Союзу забезпечується такими факторами: дією широкою мережі закупівельних організацій, завданням яких є купівля продукції сільського господарства за мінімально гарантованими цінами, митний захист цін на внутрішньому ринку і дієва система експортних субсидій.

В країнах Європейського Союзу лише $25 \%$ фермерських господарств мають власні засоби фінансування своєї діяльності, 35 \% частково залучають кредитні кошти, а 40\% фермерів повністю залежать від залучених позик. Тому проблема кредитування аграріїв $\epsilon$ актуальною для країн Європи. В багатьох країнах розробляються i впроваджуються в дію спеціальні державні програми кредитування аграрного сектору економіки. Метою цих програм $\epsilon$ сприяння в запровадженні національних i міжнародних проектів як економічного, так і соціального розвитку сільського господарства.

У Німеччині фінансову підтримку від уряду можуть отримати як одноосібники, так і сімейні підприємства, організації, кооперативи незалежно від правової форми власності. Урядова підтримка надається їм у формі субсидій, різноманітних премій, дотацій, доплат за рахунок консолідованих коштів з бюджету $\mathrm{CC}$, а також безпосередньо за рахунок бюджету землі Саксонія-Ангальт [13]. Кооперативні банки займають досить важливе місце в системі кредитування німецьких сільськогосподарських товаровиробників. Вперше вони почали функціонувати в вигляді кредитозберігальних сільських кооперативів. У країні також діє програма стимулювання інвестицій. У рамках цієї програми можна одержати пільгову державну позику: $1 \%$ річних у рахунок погашення $3,5 \%$ на будівництво житлових будинків та інших споруд у сільській місцевості [8]. У Німеччині провідними кредиторами та розпорядниками коштів аграрного сектора економіки є: Союз німецьких народних банків і банків товариств "Райффайзен", до складу якого входить більше 1470 кредитних товариств, що об'єднують в основному фермерів та інших підприємців, які працюють у сільській місцевості; система німецьких ощадних кас; сільськогосподарський рентний банк у Франкфурті; німецький іпотечний банк у Бонні; кредитний інститут відновлен- 
ня у Франкфурті; приватні іпотечні банки.

Для фермерів Німеччини, які беруть участь у програмі інвестиційного стимулювання або Загальній програмі аграрних кредитів, пільгове кредитування здійснюється у вигляді позики з 1\% річних або шляхом зниження позикового відсотка діючих кредитів на 4$7 \%$.

Сучасний високий рівень розвитку сільського господарства Швеції багато в чому обумовлений ефективною діяльністю кооперативних формувань, що мають великий досвід. Кооперацією охоплені всі господарства країни. Перші кооперативи спеціалізувалися на переробці молока і забої свиней. Пізніше виникли кооперативи, які постачали засоби виробництва, забезпечували виробничо-технічне обслуговування, а також кредитні кооперативи. У сучасній структурі фермерської кооперації Швеції виділяються наступні типи об'єднань: виробничі, постачальницькі, збутові, з переробки агропродукції, закупівельно-постачальницькі, кредитні й інші. На практиці багато об’єднань здійснюють весь спектр вертикально-координованих технологічних функцій, що забезпечує виробництво i збут того або іншого виду готової продукції. Вертикальні кооперативи займаються збором, переробкою і збутом продукції, яку виробили іiі члени. Це найбільш розвинута сфера кооперативної діяльності [8]. Останніми роками в кооперативному русі Швеції зросла роль кредитних кооперативів. Кредитні кооперативи забезпечують потреби сільськогосподарських виробників у кредитах. Кооперативи ведуть широку консуль- таційну діяльність, активно сприяють впровадженню новітніх досягнень науки.

Для Великобританії характерною рисою $є$ низький рівень державного регулювання сільського господарства. В цій країні немає спеціалізованої системи аграрних кредитів, фермерські господарства підтримуються за допомогою державних субсидій. А в останні роки аграрний сектор економіки розглядається державою як самоспроможний до відтворення й функціонування на ринкових принципах без будь-якого втручання ззовні. Для неї характерний високий рівень розподілу праці між різними фінансовими установами, широка розгалуженість і велика різноманітність різних типів фінансово-банківських інститутів. Через комерційні банки проходять різні державні субсидії країни та ЄC, що робить кредит у багатьох випадках пільговим. Найбільш крупні операції у сфері кредитування сільського господарства здійснюють Ллойд Банк (Lloyd Bank), Мідланд Банк (Midland Bank), Барклай Банк (Barclay Bank) та ін. Фінансування інвестицій у сільському господарстві здійснюється головним чином за так званим перманентним кредитом - банкір і підприємець щорічно обговорюють ставку відсотка, розмір позички, вид заборгованості в залежності від економічного становища господарства [8].

Дієвим важелем в фінансовому механізмі діяльності сільськогосподарських підприємств Франції є кредитування аграріїв. Кредитування сільського господарства забезпечують основним чином кооперативні банки. Центральну роль у системі сільського- 
сподарського кредиту у Франції відіграє «Креди агриколь». Однак за останні десятиліття до системи пільгового кредитування були підключені і інші фінансові інститути. Механізм дії пільгових кредитів у сільському господарстві цієї країни грунтується на принципі боніфікації - державного погашення банку різниці між договірною відсотковою ставкою і ставкою пільгової позички, яка була надана фермеру. Порядок розрахунку боніфікації на базі договірної відсоткової ставки введений у результаті реформи системи пільгового кредитування [14].

Фермери Франції одержують від держави допомогу, субсидії на підвищення ефективності виробництва, поліпшення умов життя, під виведення орних земель із сільськогосподарського виробництва, на підтримку родючості земель, компенсаційні виплати за роботу в районах з несприятливими природними умовами. [14]. На рисунку 2 представлено напрями підтримки держави сільськогосподарським об'єднанням. На сьогоднішній день у Франції функціонують 4000 кооперативів, SICA, асоціацій та інших некомерційних об'єднань товаровиробників.

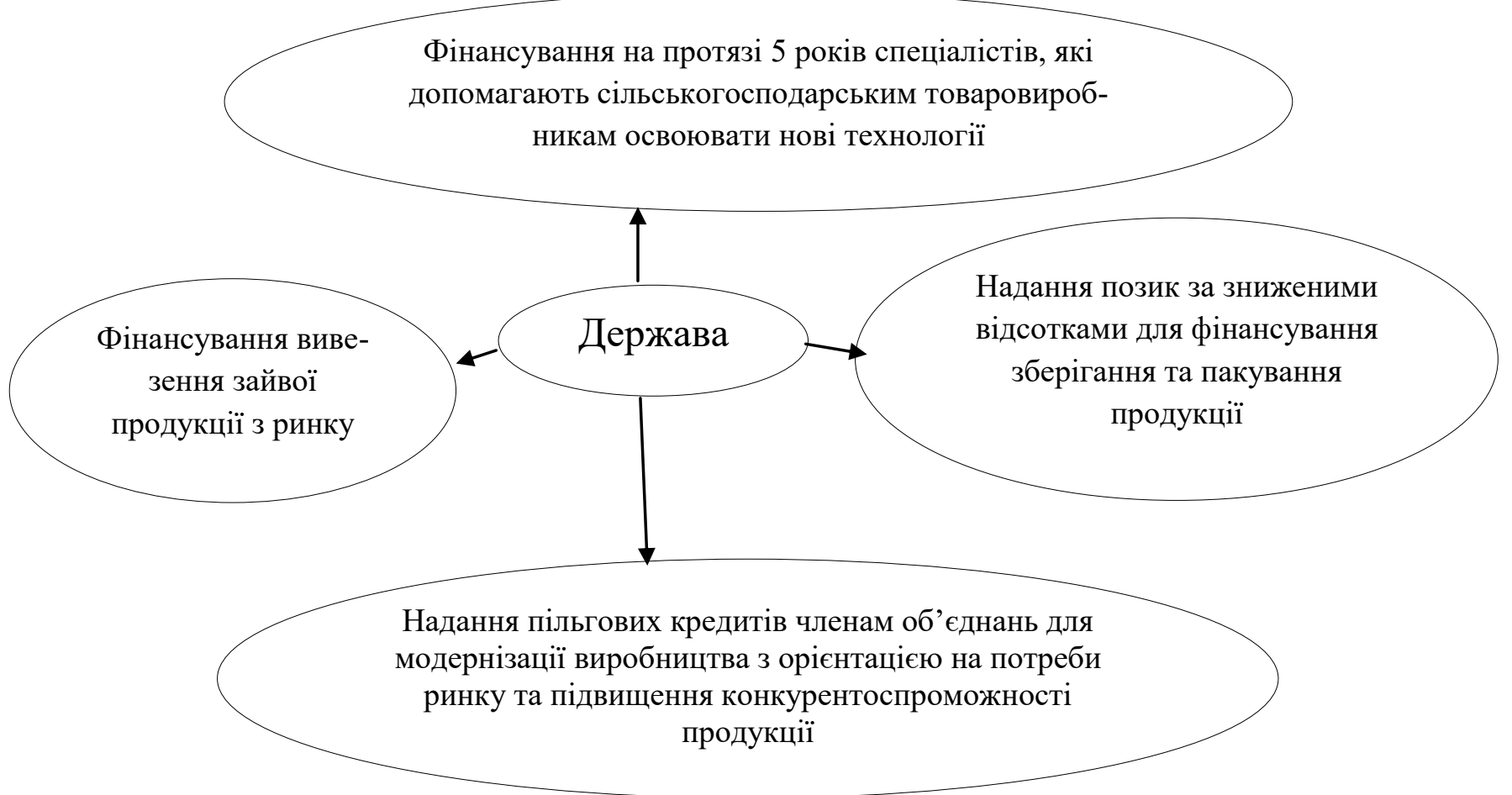

Рис. 2. Державна допомога об’єднанням сільськогосподарських товариств Франції *

* Згруповано автором за даними [15]

Заходи державного регулювання кані визвати структурні зрушення в агарного сектору в країнах Свропи і разі необхідності збалансування внутпівнічної Америки мають не тільки рішньо та міжгалузевого розподілу ринкове спрямування, а також покли- (рис. 3). 


\begin{tabular}{|c|c|c|}
\hline $\begin{array}{l}\text { Заходи, спрямовані на } \\
\text { структурні зрушення: } \\
\text { - пільгове кредитування ви- } \\
\text { робництва окремих видів } \\
\text { продукції; } \\
\text { - різні форми сприяння екс- } \\
\text { порту; } \\
\text { - надання фінансової допомоги } \\
\text { у вигляді інвестиційних над- } \\
\text { бавок; } \\
\text { - організація вільних } \\
\text { економічних зон для залучен- } \\
\text { ня інвестипій }\end{array}$ & США & $\begin{array}{l}\text { Заходи ринкового спрямуван- } \\
\text { ня: } \\
\text { - компенсації за } 1 \text { га посівних } \\
\text { площ, виведених з обігу; } \\
\text { - підтримка цін для } \\
\text { стабілізації доходів фермерів; } \\
\text { - пільгові кредити на укруп- } \\
\text { нення підприємств; } \\
\text { - підтримка методів обробітку } \\
\text { грунту, що незначно вплива- } \\
\text { ють на навколишнє середо- } \\
\text { вище за допомогою } \\
\text { компенсаційних платежів. }\end{array}$ \\
\hline $\begin{array}{l}\text { Заходи, спрямовані на } \\
\text { структурні зрушення: } \\
\text { - сприяння інвестиціям у роз- } \\
\text { виток окремих галузей і ви- } \\
\text { робництв; } \\
\text { - програма підтримки окре- } \\
\text { мих територій. }\end{array}$ & Канада & $\begin{array}{l}\text { Заходи ринкового спрямування: } \\
\text { - підтримка цін для } \\
\text { стабілізації прибутків } \\
\text { фермерів, подібна до США; } \\
\text { - страхування доходу фермерів; } \\
\text { - державна гарантія } \\
\text { відшкодування страхових } \\
\text { платежів у визначених }\end{array}$ \\
\hline
\end{tabular}

Заходи, спрямовані на структурні зрушення: - спільне фінансування програм розвитку найбільш слабких і нужденних територій; - розробка індикативних планів економічного i соціального розвитку; - організація вільних економічних зон для залучення інвестицій.

\section{Рис. 3. Основні заходи державного регулювання аграрного сектора} економіки США, Канади та країн СС

Отже, головним елементом фінансового механізму в країнах з розвинутою економікою є регулювання цін на продукцію сільського господарства державою. А саме встановлення мінімального граничного рівня для ринкових цін, нижче якого вони не можуть опускатися. Для цього використовуються два основних інструменти - підтоварні кредити та пряма державна закупівля продукції. У розвинутих країнах регулювання цін на аграрну продукцію i фермерських прибутків передбачає організацію спостережен- 
ня за динамікою низки економічних показників, у числі яких:

- витрати виробництва по групах спеціалізованих господарств (у країнах $\mathrm{CC}$ ) чи по видах виробництва (у США);

- паритет цін на засоби виробництва для сільського господарства i на сільськогосподарську продукцію;

- прибутковість ферм і галузей виробництва, а також усього сільського господарства [15].

Під час дослідження досвіду формування та регулювання фінансового механізму аграрного сектору у зарубіжних країн було встановлено, що для ефективного функціонування сільськогосподарських підприємств ці країни використовують різноманітні інструменти впливу, які доцільно було 6 використовувати для українських аграріїв, а саме:

- у державній політиці: узгодження урядових програм та планів із науковцями та практиками галузі, визначення стратегічним національним пріоритетом фінансовий розвиток сільського господарства, формування законодавчої бази відповідно до вимог й особливостей галузі (Німеччина, Японія, СС, Канада);

- у ціновій політиці: використання цінових методів регулювання інноваційної діяльності, компенсація частини собівартості продукції за умови використання інновацій у виробництві, державні закупівлі та прийняття на зберігання в державні овочесховища продукції за вигідними умовами для сільськогосподарських виробників (США);

- у аграрній політиці: розробка стратегічних завдань, сприяння вирішенню проблем галузі, а також координація співпраці виробників та науковців, організація дорадчої діяльності й впровадження обміну кваліфікованими кадрами між підприємствами й науковцями (США, країни $\mathrm{CC}$, Голландія);

- у податковій політиці: використання податкових методів стимулювання впровадження інновацій та їх фінансування серед яких застосування дослідного податкового кредиту, зниження податкового навантаження тощо (США, Франція, Німеччина, Норвегія, Австрія, Швеція);

- у кредитній політиці: відшкодування частини відсоткової ставки за рахунок державних субсидій, стимулювання шляхом запровадження пільгових відсоткових ставок кредитування окремих напрямів інноваційної діяльності тощо (Японія, країни СС, Норвегія);

- у інвестиційній політиці: сприяння залучення внутрішніх та іноземних інвестицій шляхом лібералізації законодавства, податко-вих пільг та урядових програм тощо (США, Японія, Голландія, Індія, країни (C);

- у фінансовій політиці: застосування політики стабілізації розвитку сільського господарства шляхом посилення державної фінансової підтримки, використання спеціального режиму оподаткування, кредитування та страхування тощо (країни $\mathrm{CC}$, Австралія).

Висновки. Система державної підтримки формування фінансового механізму аграрного підприємництва має бути спрямована на формування 
умов для їх інтеграції в систему субсидування, фінансово-кредитне суспільних аграрних відносин, забезпечення та податкове регулюваноскільки через обмеженість ресурсно- ня, підтримка кооперації. Загалом го потенціалу їх позиції на ринку $є$ кожна країна обирає оптимальне нестійкими. Успішний розвиток аг- співвідношення між різноманітними рарного підприємництва в провідних країнах світу зумовлена комплексним підходом до його розвитку, що відображено у програмах державної підтримки та державного регулювання. До основних форм державної підтримки та регулювання формування ефективного фінансового механізму аграрного підприємництва віднесено: цінове регулювання, пряме інструментами регулювання сільськогосподарських під-приємств залежно від національних особливостей розвитку аграрного сектора та пріоритетних цілей агропродовольчої політики. Перспективи подальших досліджень пов'язані з розробкою оптимальних джерел фінансової підтримки суб'єктів аграрного підприємництва.

\section{Список використаної літератури}

1. Майстро С. В. Сутність та напрями державного регулювання аграрного ринку в зарубіжних країнах. Державне управління: теорія та практика. 2006. № 1. URL: http://www.nbuv.gov.ua/e-journals/Dutp/2006- 1/txts/GALUZEVE/06msvrzk. pdf.

2. Танклевська Н.С. Удосконалення державної фінансової політики. Науковотеоретичний економічний журнал «Продуктивні сили Украӥни». 2009. №1 (005). C. 56-61.

3. Комарова I. В. Фінансові важелі державного регулювання аграрного сектору. Вісник Бердянського університету менеджменту $і$ бізнесу. 2013. № 1. С. 8084. URL: http://nbuv.gov.ua/j-pdf/vbumb_2013_1_19.pdf

4. Танклевська Н.С. Зарубіжний досвід фінансово-кредитного забезпечення розвитку аграрних підприємств. Вісник аграрної науки Причорномор'я. 2008. №1 (44). C.81-87.

5. Онегіна В.М. Державне регулювання цін і доходів сільськогосподарських товаровиробників: монографія. В.М. Онегіна. К.: ННЦ IАЕ. 2007

6. Михасюк I., Мельник А, Крупка М., Залога 3. Державне регулювання економіки / За ред. І.Р. Михасюка; Львів. нац. ун-т ім. І.Франка: Підручник. 2-ге вид. випр. і доповн. К.: Атіка; Ельга-Н, 2000. 592 с. 
7. Танклевська Н.С. Основні підходи щодо удосконалення фінансової політики. Вісник Львівського наџіонального аграрного університету. Економіка АПК. 2009. № 16 (1). С. 40-44.

8. Шеремет А.Д., Сайфулин Р.С. Финансы предприятий. М.: Инфра-М, 1999. С. 195

9. Олена Олійник-Данн. Чи доступні кредити для фермерів у США? URL:https://nubip.edu.ua/node/35508

10. Танклевська Н.С. Сучасні тенденції розвитку кредитної політики в аграрній сфері економіки. Науковий вісник НУБіП. 2010. Вип. 145. С. 387-395.

11. Онегіна В. М., Шибаєва Н. В.Інституційна основа аграрної політики: українські реалії й досвід США та ЄС. Економіка АПК. 2016. № 1. С. 18-24. URL: http://nbuv.gov.ua/UJRN/E_apk_2016_1_4

12. Андрійчук В. Г. Економіка аграрних підприємств. Підручник. 2-ге вид., доп. і перероблене. К.: КНЕУ, 2002. 624 с.

13. Krugman P. Development, geography, and economic theory: Cambridge M.A.: MIT Press, 1995.

14. Корецький М.X. Державне регулювання аграрної сфери у ринковій економіці: Монографія. - К.: Вид-во УАДУ, 2002. - 260 с.

15. Школенко О.Б. Інструменти державної політики захисту економічних інтересів вітчизняних товаровиробників у зарубіжних країнах. Світове господарство і міжнародні економічні відносини. URL: http:/ /www.nbuv.gov.ua/ portal/Soc_Gum/Vbumb/2010_1/2.pdf 